\title{
Acute and Sub-Acute Toxicity of Aqueous Extract of Nauclea Latifolia in Swiss Mice and in OFA Rats
}

\author{
James H Kouadio* ${ }^{* 1}$, Mathieu N Bleyere ${ }^{2}$, Mama Kone ${ }^{2}$ and Sébastien D Dano ${ }^{3}$ \\ ${ }^{1}$ Department of Biochemistry and Microbiology, UFR Agroferesterie, Daloa University, BP 150 Côte d'Ivoire \\ ${ }^{2}$ Laboratory of Physiology, Pharmacology and Phytotherapy, UFR des Sciences de la nature, Nangui Abrogoua University, 02 \\ BP 801 Abidjan 02, Côte d'lvoire. \\ ${ }^{3}$ UFR des Sciences Pharmaceutiques et Biologiques, University of Félix Houphouet BOIGNY 21 BP 632 Abidjan 21, Côte \\ d'Ivoire
}

*For correspondence: Email: jameshalbink@yahoo.fr Tel: 09544160

Revised accepted: 16 December 2013

\begin{abstract}
Purpose: To determine the dose - toxicity profile of the aqueous extract of Nauclea latifolia stem bark (AQE).

Methods: Oncin France Souche A (OFA) rats were orally administered with AQE at doses of 1.8, 18 and $180 \mathrm{mg} / \mathrm{kg}$ body weight for 28 days. In parallel, oral acute toxicity test in Swiss mice was performed with $A Q E$ at doses of 2, 4, 8 and 18g/kg body weight. Blood, urine and other biochemical markers were assessed for the rats.

Results: No death was observed after 14 days of single oral administration, and hence the $L D_{50}$ was > $18 \mathrm{~g} / \mathrm{kg}$ body weight. For sub-acute toxicity in OFA rats, an elevation of some blood parameters (platelets and erythrocytes but also eosinophils) in contrast to the low serum concentrations of biochemical markers such as aminotransferases (ALT, AST) and creatinine were recorded in rats treated with 18 and $180 \mathrm{mg} / \mathrm{kg}$ body weight. Urine analysis showed high depletion of sodium and potassium ions coupled with high loss of water.

Conclusion: Known for its diuretic property, the AQE could be beneficial against anemia and may favor blood coagulation but unfortunately may exhibit allergenic properties and cause inflammatory reactions. This study suggests the no-observed-adverse-effect-level (NOAEL) of AQE range between 1.8 and 18 $\mathrm{mg} / \mathrm{kg}$ body weight in OFA rats.
\end{abstract}

Keywords: Nauclea latifolia, Renal excretion, Hematological parameters, Biomarkers, Allergy, Inflammation, Diuretic, Toxicity

\begin{abstract}
Tropical Journal of Pharmaceutical Research is indexed by Science Citation Index (SciSearch), Scopus, International Pharmaceutical Abstract, Chemical Abstracts, Embase, Index Copernicus, EBSCO, African Index Medicus, JournalSeek, Journal Citation Reports/Science Edition, Directory of Open Access Journals (DOAJ), African Journal Online, Bioline International, Open-J-Gate and Pharmacy Abstracts
\end{abstract}

\section{INTRODUCTION}

Nauclea latifolia (Rubiaceae) commonly known as pin cushion tree is a straggling shrub or small tree native to tropical Africa and Asia and it grows up to an altitude of $200 \mathrm{~m}$. Infusions and decoctions of parts of Nauclea latifolia are commonly prescribed traditionally as a remedy for diabetes mellitus and it has been reported that the aqueous extract of Nauclea lalitifolia had been found to exert hypoglycaemic activity in alloxan-induced diabetic rats [1]. The plant is also used as a chewing stick [2] and in the treatment of ailments like gastrointestinal tract disorders, tuberculosis, sleeping sickness, prolongs menstrual flow, hypertension and malaria [3-9]. More recently, it had been reported the presence of biologically active principles in the extract with anti-nociceptive, antiinflammatory and anti-pyretic activities that 
justifies its use in malaria ethnopharmacy and subsequent development for clinical application [1]. Indeed, all plant parts of the Nauclea species are a rich source of monoterpene indol alkaloids namely indole alkaloid strictosamine [10-12] but also terpenes [13] saponines and active polyphenols [2]. Moreover, the ethanolic extract of Nauclea latifolia had been found to posses anti-hepatotoxic and trypanocidal activities [3]. Despite the numerous studies on pharmacology activities of aqueous or ethanolic extract or biologically active principles of $N$. latifolia, very few studies were reported on its systemic toxicity. The few data on the plant toxicity revealed that the $L_{50}$ was higher than $1600 \mathrm{mg} / \mathrm{kg} / \mathrm{bw}$ after intraperitoneal (IP) injection of mice [14] and alkaloid rich extracts from the Nauclea latifolia can interact in vitro with DNA of bacteria and mammalian cells, leading to G2-M cell cycle arrest and heritable DNA-damage and cause single-strand breaks in liver, kidney and blood cells [15]. But, more recently, it has been reported that repeated administration for 28 days of high doses $(200,400,600$ and $800 \mathrm{mg} / \mathrm{kg}$ body weight) of aqueous extract of Nauclea latifolia evident stem may lead to damage in the kidney and liver [16].

In Côte d'Ivoire, the aqueous extract of stem bark of $N$. latifolia (AQE) is largely and daily used against malaria and its symptoms such as fever. In these circumstances, the toxicity of plant after oral repeated administration must be clarified. The available low dose toxicity profile of $A Q E$ is extremely limited. Short-term exposure to high doses of aqueous extract of plant induces various metabolic changes and toxic responses, however, extrapolation of these findings to the long-term and low-dose exposures to human are subject is highly problematic [16]. Since, additional experiments to investigate NOAEL are indispensables, OFA rats were orally administrated with $1.8,18$ and $180 \mathrm{mg} / \mathrm{kg}$ of AQE for 28 days. In parallel, we performed oral acute toxicity study in Swiss mice.

\section{EXPERIMENTAL}

\section{Animals}

For acute toxicity, the animals used were male Swiss albino mice from the Pasteur Institute of Adiopodoumé (Abidjan) and aged 5 to 8 weeks with weight between 20 and $25 \mathrm{~g}$. The animals were acclimatized to the laboratory for 1 week prior to the test.

For sub-acute toxicity, male and female OFA rats (5 - 8 week old), weighing between 100 and 120 $\mathrm{g}$ were obtained from the Pasteur Institute of
Abidjan. The rats were housed in environmentally protected transparent polypropylene cages with stainless steel wire tops for a period of 1 week before commencement of the tests. The rats had free access to water. Experimental diets were placed in special containers to minimize spillage. Environmental conditions included $23-25^{\circ} \mathrm{C}$, relative humidity of $45-55 \%$, and a 12-h light/dark cycle.

\section{Plant}

The plant material consists of stem bark of the plant which was dried and ground into powder before diluting in water. The aqueous extract (AQE) was obtained by maceration for $24 \mathrm{~h}$ as traditional used in Côte d'Ivoire. The extract was filtered and lyophilized and the dried residue was diluted appropriately with water for oral administration to the experimental animals.

\section{Acute toxicity test}

The acute toxicity study was performed according to OECD 401 Guidelines for testing of chemicals [17]. The animals were placed in special cages for 7 days for acclimatization before the experiment. At the end of the seventh day, the animals were subjected to fasting for 24 hours before oral administration of different doses of AQE. The mice were randomly divided into 5 groups of 3 female mice. Group I: normal control group, and the mice received water; Group II: $2 \mathrm{~g} / \mathrm{kg}$ body weight AQE; Group III: 4 $\mathrm{g} / \mathrm{kg}$ body weight AQE; Group IV: $8 \mathrm{~g} / \mathrm{kg}$ body weight AQE; and Group V: $18 \mathrm{~g} / \mathrm{kg}$ body weight AQE. After administration of the extract, the animals were observed every $30 \mathrm{~min}$ for $8 \mathrm{~h}$ on the first day and once daily for 14 days. During this period, the liveliness, sensibility to painful stimulation, visual acuity and texture of the faeces were assessed. The $L_{50}$ of $A Q E$ was investigated based on the eventual observed mortality.

\section{Sub-acute toxicity test}

The protocol of sub-acute toxicity study performed according to from OECD 407 Guidelines for testing of chemicals [18]. The protocol was approved by the committee of Bioethics of Nangui Abrogoua University, Abidjan (Côte d'lvoire). Total of 40 rats (20 males and 20 females) was randomly divided into 4 groups ( $\mathrm{n}=$ 10 per group with 5 females +5 males) and housed under standard husbandry condition for one week before the experiment and allowed with standard feed in solid (balls). The animals were divided into the following 4 groups: Group A: normal control group and mice received water; 
Group.B: $1.8 \mathrm{mg} / \mathrm{kg}$ body weight AQE; Group C: $18 \mathrm{mg} / \mathrm{kg}$ body weight AQE; and Group D: 180 $\mathrm{mg} / \mathrm{kg}$ body weight $\mathrm{AQE}$. Each group received the appropriate vehicle (water) and AQE daily by oral administration for 28 days. All the rats were weighed on a Sartorius balance (ED 224S, Germany), with $0.0001 \mathrm{mg}$ accuracy, prior to treatment. Urine and blood were collected from the rats at the end of each week for urine and hematological analysis. After 28 days, blood and urine were again collected, all the animals euthanized using chloroform, and the tissues examined examined.

\section{Urinalysis}

Urine samples collected by refrigerating metabolic cages (Tecniplast, Bugugiate, Italy) were analyzed for $\mathrm{pH}$, albumin, glucose, ketone body using dipsticks (Ames Labstix Bayer Dignostic). In addition, the urinary sodium and potassium ions were analyzed using a PFP7 flame photometer (Jenway).

\section{Evaluation of hematological parameters}

The analysis of blood samples was performed using an analyzer, Beckman Coulter T540. The hematological parameters including the number of leukocytes, erythrocytes, hemoglobin ( $\mathrm{Hb})$ concentration and the platelet count were determined. White blood cells or leukocytes were analyzed using pap test with May-Grünwald Giemsa (MGG) blood staining for the determination of percentage (\%) of leukocytes including lymphocytes, monocytes and phagocytes, and granulocytes (neutrophils, eosinophils and basophils).

\section{Assessment of biochemical parameters}

The serum biochemistry parameters including aspartate aminotransferase (AST), alanine aminotransferase (ALT), creatinine and urea were evaluated spectrophotometrically using an automated HumaStar 80 (Human $\mathrm{GmbH}$, Germany).

\section{Statistical analysis}

The data generated were statistically processed using SPSS 11.19 statistical software. Analysis of variance (ANOVA), with Tukey post-hoc test to identify the variable(s) with very significant differences vis-a-vis the control group, was used to analyse the data from the evaluation of hematological and biochemical parameters. At $95 \%$ confidence interval, $p$ values $<0.05$ were considered to be statistically significant.

\section{RESULTS}

\section{Acute toxicity}

Following the administration of single dose of 2 , 4,8 and $18 \mathrm{~g} / \mathrm{kg}$ body weight of AQE to mice, no death was registered after 14 days posttreatment.

\section{Sub-acute toxicity}

\section{General observation and body weight}

At the end of the 4th week of the experiment (day 28), no variation of the vivacity, sensitivity to noise and to painful stimulation was noted in both experimental and control groups. In addition, the macroscopic observation of each animal's tissues was not revealed any changes but, the water was rich in the faeces of experimental animals and as compared to control, animals treated with $A Q E$ at doses 1.8 and $18 \mathrm{mg} / \mathrm{kg}$ increased in body weights, in contrast to those treated with $180 \mathrm{mg} / \mathrm{kg}$ of extract (Table 1).

\section{Biomarkers}

The results of hematology and serum biochemical examinations are summarized in Tables 2 - 5. Serum creatinine, AST and ALT decreased in treated animals by AQE at doses of

Table 1: Weight of female and male rats after treatment with AQE at various doses for 4 weeks

\begin{tabular}{|c|c|c|c|c|c|}
\hline Dose (mg/kg) & Day 0 & Day 7 & Day 14 & Day 21 & Day 28 \\
\hline \multicolumn{6}{|l|}{ Males } \\
\hline Control & $82 \pm 2.7$ & $88 \pm 2.5$ & $95.5 \pm 2$ & $97.5 \pm 3$ & $105 \pm 2.5$ \\
\hline 1.8 & $79 \pm 2.8$ & $85 \pm 2.3$ & $90.5 \pm 3$ & $103 \pm 2.8$ & $113 \pm 3^{*}$ \\
\hline 18 & $78 \pm 2.5$ & $88 \pm 3$ & $91 \pm 3.2$ & $94 \pm 3.6$ & $100 \pm 3.2$ \\
\hline 180 & $80 \pm 3$ & $87 \pm 2.4$ & $99 \pm 2.2$ & $101 \pm 3$ & $93 \pm 3.2^{*}$ \\
\hline \multicolumn{6}{|l|}{ Females } \\
\hline Control & $80 \pm 2.3$ & $86 \pm 3$ & $90 \pm 2.9$ & $91 \pm 2.9$ & $102.5 \pm 3$ \\
\hline 1.8 & $78 \pm 2.4$ & $84 \pm 2.6$ & $96 \pm 3$ & $105 \pm 3$ & $115 \pm 2.7^{*}$ \\
\hline 18 & $77 \pm 3$ & $87 \pm 4$ & $88 \pm 3.5$ & $89 \pm 3.2$ & $91 \pm 3^{*}$ \\
\hline 180 & $81 \pm 2.8$ & $88 \pm 3$ & $89 \pm 2.7$ & $91 \pm 3.2$ & $86 \pm 3^{*}$ \\
\hline
\end{tabular}


Table 2: Serum chemistry of OFA rats administered with AQE at doses of $1.8,18$ and 180 $\mathrm{mg} / \mathrm{kg}$ on Day 28

\begin{tabular}{lllll}
\hline Dose $(\mathrm{mg} / \mathrm{kg})$ & AST $(\mathbf{I U} / \mathbf{l})$ & ALT $(\mathbf{I U} / \mathbf{l})$ & Urea $(\mathbf{g} / \mathbf{l})$ & Créatinine $(\mathbf{m g} / \mathbf{d l})$ \\
\hline Male & & & & \\
$\quad$ Control & $198.7 \pm 21$ & $64.55 \pm 6$ & $0.89 \pm 0.12$ & $30.3 \pm 2$ \\
1.8 & $169.8 \pm 24$ & $55.7 \pm 4.5$ & $0.73 \pm 0.1$ & $28.3 \pm 1.8$ \\
$\quad 18$ & $* 115.2 \pm 15$ & $* 40.4 \pm 3.3$ & $0.69 \pm 0.09$ & $* 20.5 \pm 2.2$ \\
$\quad 180$ & $* 82.3 \pm 17$ & $* 32.2 \pm 7.1$ & $0.89 \pm 0.15$ & $* 17.5 \pm 1.2$ \\
Female & & & & \\
$\quad$ Control & $163.5 \pm 10.6$ & $65.6 \pm 8$ & $0.62 \pm 0.08$ & $35 \pm 3.8$ \\
1.8 & $161.5 \pm 14$ & $51.5 \pm 6.3$ & $0.65 \pm 0.06$ & $28.33 \pm 3.2$ \\
18 & ${ }^{*} 92.6 \pm 12$ & $* 40.9 \pm 3.2$ & $0.69 \pm 0.04$ & $* 18.4 \pm 2.5$ \\
180 & ${ }^{*} 62.6 \pm 9.8$ & $* 28.6 \pm 2.7$ & $0.70 \pm 0.07$ & $* 16.4 \pm 1.5$ \\
\hline
\end{tabular}

*Significantly different from control group at $p<0.05$

Table 3: Hematological data for male OFA rats treated with $A Q E$ for 4 weeks

\begin{tabular}{|c|c|c|c|c|c|c|c|c|}
\hline \multirow{3}{*}{ Males (1) } & \multicolumn{4}{|l|}{ Day 7} & \multicolumn{4}{|l|}{ Day 14} \\
\hline & \multicolumn{4}{|c|}{ AQE dose $(\mathrm{mg} / \mathrm{kg} / \mathrm{bw})$} & \multicolumn{4}{|c|}{ AQE dose $(\mathrm{mg} / \mathrm{kg} / \mathrm{bw})$} \\
\hline & 0 & 1.8 & 18 & 180 & 0 & 1.8 & 18 & 180 \\
\hline Leukocytes & $5.1 \pm 0.9$ & $4.8 \pm 1.2$ & $4.6 \pm 1$ & $4.6 \pm 0.7$ & $4.6 \pm 1.1$ & $4.7 \pm 1.4$ & $4.7 \pm 0.5$ & $4.7 \pm 0.9$ \\
\hline Neutrophils (\%) & 20 & 22 & 21 & 21 & 24 & 21 & 21 & 27 \\
\hline$\left(10^{9} / \mathrm{l}\right)$ & 0.8 & 0.88 & 0.84 & 0.84 & 0.94 & 0.84 & 0.84 & 1.08 \\
\hline Eosinophils (\%) & 0 & 0 & 0 & *2 & 0 & 0 & 0 & *2 \\
\hline$\left(10^{y} / \mathrm{l}\right)$ & 0 & 0 & 0 & $* 0.08$ & 0 & 0 & 0 & $* 0.08$ \\
\hline Basophils (\%) & 0 & 0 & 0 & 0 & 0 & 0 & 0 & 0 \\
\hline Monocytes (\%) & 0 & 0 & 0 & 0 & 0 & 0 & 0 & 0 \\
\hline Lymphocytes (\%) & 86 & 79 & 76 & *74 & 74 & 78 & 78 & 71 \\
\hline$\left(10^{y} /\right)$ & 4.3 & 4 & 3.8 & 3.7 & 3.7 & 3.9 & 3.9 & 3.6 \\
\hline Erythrocytes & $3.1 \pm 0.3$ & $3.6 \pm 0.4$ & $2.9 \pm 0.2$ & $3.1 \pm 0.4$ & $3.7 \pm 0.2$ & $3.7 \pm 0.3$ & $4.1 \pm 0.5$ & $4.2 \pm 0.4$ \\
\hline Hemoglobin & $6.4 \pm 0.4$ & $8.2 \pm 0.9$ & $5.7 \pm 0.4$ & $5.5 \pm 0.6$ & $7.3 \pm 0.5$ & $7.3 \pm 0.3$ & $8.1 \pm 0.6$ & $5.5 \pm 0.4$ \\
\hline \multirow[t]{2}{*}{ Platelets } & $366 \pm 12$ & $480 \pm 16$ & $420 \pm 21$ & $391 \pm 19$ & $434 \pm 11$ & $392 \pm 16$ & $424 \pm 14$ & $434 \pm 10$ \\
\hline & \multicolumn{4}{|c|}{ Day 21} & \multicolumn{4}{|l|}{ Day 28} \\
\hline \multirow[t]{2}{*}{ Males (2) } & \multicolumn{4}{|c|}{ AQE dose $(\mathrm{mg} / \mathrm{kg} / \mathrm{bw})$} & \multicolumn{4}{|c|}{ AQE dose $(\mathrm{mg} / \mathrm{kg} / \mathrm{bw})$} \\
\hline & 0 & 1.8 & 18 & 180 & 0 & 1.8 & 18 & 180 \\
\hline Leukocytes & $4.8 \pm 1.1$ & $4.9 \pm 1$ & $4.9 \pm 0.9$ & $4.9 \pm 1.3$ & $4.8 \pm 0.9$ & $4.8 \pm 0.7$ & $4.7 \pm 1.2$ & $4.7 \pm 0.9$ \\
\hline Neutrophils (\%) & 23 & 25 & *13 & $* 16$ & 14 & 16 & $* 24$ & 21 \\
\hline$\left(10^{y} / I\right)$ & 0.92 & 1 & ${ }^{*} 0.52$ & ${ }^{*} 0.64$ & 0.56 & 0.6 & *0.94 & 0.84 \\
\hline Eosinophils (\%) & 1 & 1 & 0 & 2 & 0 & 0 & 0 & *2 \\
\hline$\left(10^{y} / I\right)$ & 0.04 & 0.04 & 0 & 0.08 & 0 & 0 & 0 & $* 0.08$ \\
\hline Basophils (\%) & 0 & 0 & 0 & 0 & 0 & 0 & 0 & 0 \\
\hline Monocytes (\%) & 0 & 0 & 0 & 0 & 0 & 0 & 0 & 0 \\
\hline Lymphocytes (\%) & 76 & 77 & *87 & *84 & 85 & 84 & *76 & *76 \\
\hline$\left(10^{9} / \mathrm{I}\right)$ & 3.8 & 3.9 & 4.4 & 4.2 & 4.3 & 4.2 & 3.8 & 3.8 \\
\hline Erythrocytes & $4.3 \pm 0.5$ & $4.5 \pm 0.4$ & $4.7 \pm 0.6$ & $4 \pm 0.3$ & $4.8 \pm 0.2$ & $4.7 \pm 0.4$ & $4.8 \pm 0.3$ & 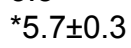 \\
\hline Hemoglobin & $8.4 \pm 0.6$ & $8.3 \pm 0.3$ & $9.5 \pm 0.9$ & $7.9 \pm 0.4$ & $9.3 \pm 0.8$ & $8.3 \pm 0.5$ & $10.5 \pm 1$ & $* 11.5 \pm 1$ \\
\hline Platelets & $511 \pm 20$ & $528 \pm 19$ & *764 \pm 9 & $* 723 \pm 8$ & $502 \pm 19$ & $479 \pm 11$ & $* 574 \pm 9$ & * $577 \pm 12$ \\
\hline
\end{tabular}

18 and $180 \mathrm{mg} / \mathrm{kg}$ but the change was more pronounced at the latter dose. Erythrocytes, hemoglobin and platelets decreased at day 14 only in female rats treated at a dose of $18 \mathrm{mg} / \mathrm{kg}$ of AQE. On day 21, however, platelets increased in male rats at doses i.e. 18 and $180 \mathrm{mg} / \mathrm{kg}$ body weight. Moreover, the rates of erythrocytes and hemoglobin were elevated at day 28 only for males at dose of $180 \mathrm{mg} / \mathrm{kg}$ body weight. The number of lymphocytes increased at 21 day but decreased at days 7 and 28 in treated groups (18 and $180 \mathrm{mg} / \mathrm{kg}$ body weight). Eosinophils were elevated in animals treated at a dose of 180 $\mathrm{mg} / \mathrm{kg}$ over the period of the test. The number of neutrophils decreased on day 21 for animals that received high doses of $A Q E$ but increased at day 28 only with the highest dose in male rats, i.e., Group V (Tables 2 - 4).

The results of urinalysis showed no significant ketone, glucose and albumin in the urine of all the treated animals throughout the duration of the experiment. Urinary $\mathrm{pH}$ ranged from 8.5 to 9 while potassium and sodium ions (Tables 5 and 6) showed significant variation from control. High depletion of sodium ion was observed in all 
Table 4: Hematological data for female OFA rats administered with AQE for 4 weeks

\begin{tabular}{|c|c|c|c|c|c|c|c|c|}
\hline \multirow[b]{2}{*}{ Females (1) } & \multicolumn{4}{|l|}{ Day 7} & \multicolumn{4}{|l|}{ Day 14} \\
\hline & \multicolumn{4}{|c|}{ AQE dose $(\mathrm{mg} / \mathrm{kg})$} & \multicolumn{4}{|c|}{ AQE dose $(\mathrm{mg} / \mathrm{kg})$} \\
\hline & 0 & 1.8 & 18 & 180 & 0 & 1.8 & 18 & 180 \\
\hline Leukocytes & $4.4 \pm 0.6$ & $4.8 \pm 0.5$ & $4.2 \pm 0.3$ & ${ }^{*} 5 \pm 0.3$ & $4.7 \pm 0.5$ & $4.9 \pm 0.3$ & $4.8 \pm 0.4$ & $4.7 \pm 0.6$ \\
\hline Neutrophils (\%) & 22 & 21 & 23 & 23 & 27 & 22 & 25 & 24 \\
\hline$\left(10^{y} /\right)^{\prime}$ & 0.88 & 0.84 & 0.92 & 0.92 & 1.08 & 0.88 & 1 & 0.94 \\
\hline Eosinophils (\%) & 0 & 0 & 0 & *5 & 0 & 0 & 0 & $* 5$ \\
\hline$\left(10^{y} /\right)$ & 0 & 0 & 0 & ${ }^{*} 0.2$ & 0 & 0 & 0 & ${ }^{*} 0.2$ \\
\hline Basophils (\%) & 0 & 0 & 0 & 0 & 0 & 0 & 0 & 0 \\
\hline Monocytes (\%) & 0 & 0 & 0 & 0 & 0 & 0 & 0 & 0 \\
\hline Lymphocytes (\%) & 70 & 78 & 65 & 80 & 73 & 80 & 75 & 71 \\
\hline$\left(10^{y} /\right)^{\prime}$ & 3.5 & 3.9 & 3.3 & 4 & 3.7 & 4 & 3.8 & 3.6 \\
\hline Erythrocytes & $3 \pm 0.1$ & $3.2 \pm 0.1$ & $3 \pm 0.2$ & $3.1 \pm 0.1$ & $4.2 \pm 0.3$ & $4.1 \pm 0.1$ & 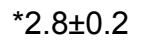 & $3 \pm 0.1$ \\
\hline Hemoglobin & $5.4 \pm 0.3$ & $6.6 \pm 0.2$ & $5.3 \pm 0.1$ & $5.5 \pm 0.1$ & $7.9 \pm 0.4$ & $8.2 \pm 0.5$ & $* 5.5 \pm 0.3$ & $6.3 \pm 0.1$ \\
\hline Platelets & $424 \pm 19$ & $471 \pm 16$ & $452 \pm 15$ & $456 \pm 12$ & $449 \pm 20$ & $378 \pm 16$ & *241士18 & $440 \pm 13$ \\
\hline \multirow{3}{*}{ Females (2) } & \multicolumn{4}{|l|}{ Day 21} & \multicolumn{4}{|c|}{ Day 28} \\
\hline & \multicolumn{4}{|c|}{ AQE dose $(\mathrm{mg} / \mathrm{kg})$} & \multicolumn{4}{|c|}{ AQE dose $(\mathrm{mg} / \mathrm{kg})$} \\
\hline & 0 & 1.8 & 18 & 180 & 0 & 1.8 & 18 & 180 \\
\hline Leukocytes & $4.7 \pm 0.8$ & $4.8 \pm 0.5$ & $5.1 \pm 0.9$ & $4.9 \pm 0.8$ & $4.8 \pm 0.6$ & $4.8 \pm 0.9$ & $4.7 \pm 0.7$ & $4.7 \pm 0.6$ \\
\hline Neutrophils (\%) & 26 & 20 & *14 & 20 & 23 & 19 & 20 & 23 \\
\hline$\left(10^{9} /\right)$ & 1.04 & 0.8 & ${ }^{*} 0.78$ & 0.8 & 0.92 & 0.76 & 0.8 & 0.92 \\
\hline Eosinophils (\%) & 1 & 2 & 0 & *4 & 0 & 0 & 1 & $* 7$ \\
\hline$\left(10^{9} /\right)$ & 0.04 & 0.08 & 0 & ${ }^{*} 0.16$ & 0 & 0 & 0.04 & ${ }^{*} 0.28$ \\
\hline Basophils (\%) & 0 & 0 & 0 & 0 & 0 & 0 & 0 & 0 \\
\hline Monocytes (\%) & 0 & 0 & 0 & 0 & 0 & 0 & 0 & 0 \\
\hline Lymphocytes (\%) & 72 & 78 & *86 & 78 & 77 & 81 & 78 & 70 \\
\hline$\left(10^{9} /\right)$ & 3.6 & 3.9 & $* 4.3$ & 3.9 & 3.9 & 4.1 & 3.9 & 3.5 \\
\hline Erythrocytes & $5 \pm 0.2$ & $3.8 \pm 0.2$ & $4.2 \pm 0.5$ & $4.6 \pm 0.3$ & $5.6 \pm 0.3$ & $5.6 \pm 0.2$ & $5.4 \pm 0.2$ & $5.5 \pm 0.4$ \\
\hline Hemoglobin & $9.3 \pm 0.5$ & $7.1 \pm 0.3$ & $7.7 \pm 0.3$ & $9.1 \pm 0.5$ & $12.1 \pm 1$ & $11.9 \pm 0.8$ & $11.3 \pm 1$ & $11 \pm 0.9$ \\
\hline Platelets & $502 \pm 17$ & $449 \pm 12$ & $549 \pm 15$ & *739 79 & $573 \pm 13$ & $607 \pm 17$ & $590 \pm 18$ & $554 \pm 16$ \\
\hline
\end{tabular}

Table 5: Urinary concentrations of sodium $\left(\left(\mathrm{Na}^{+}\right)\right.$and potassium $\left(\mathrm{K}^{+}\right)$ions for OFA male rats administered with AQE

\begin{tabular}{|c|c|c|c|c|c|c|c|c|}
\hline Males & Day 7 & & Day 14 & & Day 21 & & Day 28 & \\
\hline $\begin{array}{l}\text { Dose } \\
\text { (mg/kg) }\end{array}$ & $\begin{array}{l}\mathrm{Na}^{+} \\
(\mathrm{mEq} / \mathrm{l})\end{array}$ & $\begin{array}{l}K^{+} \\
(m E q / I)\end{array}$ & $\begin{array}{l}\mathrm{Na}^{+} \\
(\mathrm{mEq} / \mathrm{l})\end{array}$ & $\begin{array}{l}K^{+} \\
(m E q / I)\end{array}$ & $\begin{array}{l}\mathrm{Na}^{+} \\
(\mathrm{mEq} / \mathrm{l})\end{array}$ & $\begin{array}{l}K^{+} \\
(m E q / l)\end{array}$ & $\begin{array}{l}\mathrm{Na}^{+} \\
(\mathrm{mE} / \mathrm{l} / \mathrm{l})\end{array}$ & $\begin{array}{l}K^{+} \\
(m E q / I)\end{array}$ \\
\hline Control & $68.7 \pm 4$ & $113.6 \pm 8$ & $58.3 \pm 3.7$ & $119 \pm 14$ & $72.1 \pm 10$ & $167.5 \pm 24$ & $56 \pm 7$ & $158 \pm 16$ \\
\hline 1.8 & $66 \pm 5$ & $116.5 \pm 7.3$ & $64.7 \pm 5$ & $141.7 \pm 16$ & $62.17 \pm 7.5$ & $139.8 \pm 21$ & $51 \pm 6.5$ & $147 \pm 20$ \\
\hline 18 & $66.8 \pm 4.6$ & $103.1 \pm 7$ & $76.2 \pm 4.3$ & $146.8 \pm 14$ & $60.74 \pm 6.2$ & $147 \pm 42$ & $63.7 \pm 9$ & $132.2 \pm 19$ \\
\hline 180 & 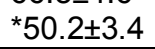 & $* 74.2 \pm 6$ & 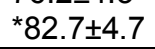 & ${ }^{*} 90 \pm 4.3$ & *34. $3 \pm 5.6$ & *59.3 \pm 9.7 & *91.8ะ8.6 & $143.4 \pm 22$ \\
\hline
\end{tabular}

*Significantly different from control group at $p<0.05$

Table 6: Urinary concentrations of sodium $\left(\left(\mathrm{Na}^{+}\right)\right.$and potassium $\left(\mathrm{K}^{+}\right)$ions for OFA female rats administered with AQE

\begin{tabular}{|c|c|c|c|c|c|c|c|c|}
\hline \multirow{2}{*}{$\begin{array}{l}\text { Females } \\
\text { Dose } \\
\text { (mg/kg) }\end{array}$} & \multicolumn{2}{|l|}{ Day 7} & \multicolumn{2}{|l|}{ Day 14} & \multicolumn{2}{|l|}{ Day 21} & \multicolumn{2}{|l|}{ Day 28} \\
\hline & $\begin{array}{l}\mathrm{Na}^{+} \\
(\mathrm{mEq} / \mathrm{l})\end{array}$ & $K^{+}(m E q / l)$ & $\begin{array}{l}\mathrm{Na}^{+} \\
(\mathrm{mEq} / \mathrm{l})\end{array}$ & $\begin{array}{l}K^{+} \\
(m E q / I)\end{array}$ & $\begin{array}{l}\mathrm{Na}^{+} \\
(\mathrm{mE} / \mathrm{l} / \mathrm{l})\end{array}$ & $\begin{array}{l}K^{+} \\
(m E q / I)\end{array}$ & $\begin{array}{l}\mathrm{Na}^{+} \\
(\mathrm{mE} / \mathrm{l} / \mathrm{l})\end{array}$ & $\begin{array}{l}K^{+} \\
(m E q / l)\end{array}$ \\
\hline Control & $40.9 \pm 7.9$ & $144.2 \pm 21$ & $80.7 \pm 9$ & $128 \pm 9.2$ & $108 \pm 18$ & $131.2 \pm 8.2$ & $53.7 \pm 4$ & $126.7 \pm 9.2$ \\
\hline 1.8 & 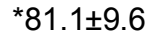 & $131 \pm 23$ & $72.6 \pm 6.5$ & $120.9 \pm 7.5$ & $104 \pm 13$ & $135.7 \pm 14$ & $47 \pm 4$ & $129 \pm 10$ \\
\hline 18 & 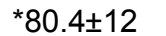 & $125.7 \pm 17$ & $71.4 \pm 8$ & $135.1 \pm 9$ & $94 \pm 17$ & $150.3 \pm 22$ & $79.3 \pm 4$ & $119.96 \pm 9$ \\
\hline 180 & *107.7 \pm 13 & 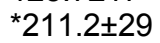 & *58.6 \pm 4.5 & *101士5.5 & 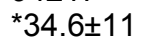 & 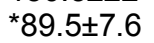 & ${ }^{*} 91.8 \pm 4$ & $144.3 \pm 12$ \\
\hline
\end{tabular}

*Significantly different from control group at $p<0.05$

female rats treated by $A Q E$ at day 7 and this high depletion was also observed on day 28 only in the female rats that received $180 \mathrm{mg} / \mathrm{kg}$ but decreased on days 14 and 21, compared to control. At the same dose, in male rats, sodium ion levels were elevated on days 14 and 28 but diminished on days 7 and 21. For potassium ion, at dose of $180 \mathrm{mg} / \mathrm{kg}$ body weight, the values of unary concentration decreased only on days 7 , 14 and 21 in males and on days 14 and 21 in female rats, but showed an elevation on day 7 . 


\section{DISCUSSION}

The maximum acute dose of AQE administered $(18 \mathrm{~g} / \mathrm{kg})$ is 7 times greater than $2.5 \mathrm{~g} / \mathrm{kg}$ recommended for screening of plant toxicity [19]. For comparison, it was found that the $\mathrm{LD}_{50}$ of mebendazole was $640 \mathrm{mg} / \mathrm{kg}$ body weight in mouse [20]. The results of this study are supported by previous findings obtained from intraperitoneal and oral administration to mouse of both aqueous and ethanol extracts of the root and stem bark with the highest dose of the plant at $16 \mathrm{~g} / \mathrm{kg}[14,21]$. Therefore, the results of acute toxicity in the present study confirm the low toxicity of a single consumption of the stem bark extract of Nauclea latifolia as previously reported $[14,21]$.

Although acute toxicity helps to determine substances that are non-toxic, it is important to assess sub-acute toxicity profile because it helps to evaluate morphological and physiological changes in organs. Toxicological evaluation by repeated doses have been generally accepted as a fundamental test for safety assessment. Although there are previous reports on the toxicological profile of AQE [16], however, available toxicological profiles of low doses of the plant including hematological parameters and NOAEL are limited. Furthermore, there is controversy over the sub-acute toxicity of AQE in rats $[16,22]$. It has previously been reported that the aqueous extract of $N$. latifolia did not significantly affect the liver, kidney, heart and hematological system of rats but could cause reduction in feeding and water consumption as well as body weight at the highest dose tested [22]. However, more recently, evident liver and kidney toxicities have been revealed [16].

In the present study, the mean gain in weight was high in groups which received AQE which may be due to the beneficial effect of the extract. After the consumption of AQE, animals showed a slight stimulation of appetite for food and water. It is known that in addition to their therapeutic properties, medicinal plants can affect positively the nutritional status of an animal [23]. However, the highest dose of AQE causedserious weight loss in the rats which could be explained by the high urinary excretion of water to the diuretic properties of $N$. latifolia .

With the exception of serum urea, all serum parameters analyzed, namely, creatinine, ALT and AST decreased in a time- and concentrationdependent manner. Since, these serum parameters were analyzed only at the end of the experiment, i.e., day 28 , the high excretion of these parameters coincided with the very high urinary excretion of blood sodium and potassium ions. The kidney plays a very important role in the removal of metabolic wastes from the blood stream. Its functionality, therefore, can be assessed among many others by determining the serum concentration of excretory constituents [24]. The significant decrease in serum creatinine, sodium ion and potassium ion was probably linked to metabolic alkalosis as revealed by the values of urine $\mathrm{pH}$ of $8-9$ for the 4 weeks of study.

AST and ALT levels in the groups which received high doses of the plant extract (18 and 180 $\mathrm{mg} / \mathrm{kg}$ ) for 28 days may be suggestive of an alteration in the secretory and excretory functions of the kidney [24,25] caused by the extract of $N$. latifolia stem. Our findings are partially supported by a previous report [16] which found a decrease in serum creatinine and urea but increase in serum AST and ALT in rats treated with the aqueous extract of $N$. latifolia. The authors concluded that the extract of the plant may not only adversely interfere with amino acid metabolism of the liver but also cause a destruction of liver tissue in a time- and concentration-dependent manner [16]. That could explain the elevation of serum ALT and AST in contrast to the decrease in these serum parameters in the present study. The doses of AQE used in the present study $(1.8,18$ and 180 $\mathrm{mg} / \mathrm{kg}$ ) when compared to those previously used $(200,400,600$ and $800 \mathrm{mg} / \mathrm{kg})$ [16] are not high enough to cause damage to liver tissue based on serum AST and ALT elevation.

The effect of AQE on erythrocytes, hemoglobin and platelets was slightly beneficial at 18 and $180 \mathrm{mg} / \mathrm{kg}$ doses on days 21 and 28. AQE probably exerts activity against anemia and may also enhance the blood coagulation. The effect of AQE on lymphocytes count was beneficial on day 21 of the experiment but on day 28 , caused a reduction in lymphocytes indicating possible lymphocyte cell death. Moreover, AQE induced eosinophilia which occurs in some allergic diseases and infestations by large parasites. More likely, however, AQE may contain biologically active principles with allergenic properties. AQE modulated (diminished and increased) time-dependently neutrophil count; elevation of neutrophils could indicate inflammatory diseases induced by AQE or could have been a killer of neutrophils.

\section{CONCLUSION}

Oral exposure of acute doses of AQE did not cause mortality. Low doses, however, led to weight gain. Although AQE may possess 
beneficial effect against anemia and favor blood coagulation (platelets elevation); unfortunately, it seems that it may contain principles that exert that have allergenic and inflammatory properties.

\section{REFERENCES}

1. Gidado A, Ameh DA, Atawodi SE. Effects of Nauclea latzfolia leaves aqueous extracts on blood glucose levels of normal and alloxan-induced diabetic rats. Afr. J. Biotechnol. 2005; 4: 91-93.

2. Asubiojo OI, Guinn VP, Okunuga A. Multi-element Analysis of Nigerian Chewing Sticks by Instrumental Neuron Activation Analysis. J. Radio Anal. Chem. 1982; 74: 149 -156.

3. Madubunyi II. Anti-Hepatotoxic and Trypanocidal Activities of the Ethanolic Extract of Nauclea latifolia Root Bark. J. Herbs Spices Med Plants. 1995; 3: 2353.

4. Deeni $Y Y$, Hussain HSN. Screening for antimicrobial activity and for alkaloids of Nauclea latifolia $J$ Ethnopharmacol. 1991; 35: 91-96

5. Kerharo J. Historic and Ethnopharmacognosic Review on the Belief and Traditional Practices in the Treatment of Sleeping Sickness in West Africa. Bull. Soc. Med. Afr. Noire Lang. FR. 1974; 19: 400-420.

6. Elujoba AAA. Female Infertility in the Hands of Traditional Birth Attendants in South-West Nigeria. Fitoterapia. 1995; 66: 239-248

7. Akabue P, Mittal GC. Clinical Evaluation of a Traditional Herbal Practice in Nigeria: a Preliminary Rep. J. Ethnopharmacol. 1982; 6: 355-359.

8. Kokwaro, JO. Medicinal Plants of East Africa. Nairobi: University of Nairobi Press, 1976; pp 368.

9. Boye GL. Studies on Antimalarial Action of Cryptolepis sanguinolenta Extract. Proc. Int. Syp. On East-West Med. Seoul, Korea, 1990; pp 243-251.

10. Shigemori $H$, Kagata $T$, Ishiyama $H$. New monoterpene alkaloids from Nauclea latifolia. Chem Pharm Bull. 2003; 51: 58-61

11. Hotellier F, Delaveau P, Pousset JL. Alkaloids and Glycoalkaloids from Leaves of Nauclea latifolia. Planta. Med. 1979; 35: 242-250.

12. Abreu $P$, Pereira A. New Indole Alkaloids from Sarcocephalus latifolius. Nat. Prod. Lett. 2001; 5: 43 -48 .

13. Morah FNI. Naucledal and Epinaucledal from an Antiviral Preparation from Nauclea latifolia. Global J. Pure Appl. Sci. 1995; 1: 59-62.
14. Kaboré ZI: Guissov, LP: Sovrabie S. Etude pharmacochimique de Nauclea latifolia Sm. (Rubiaceae). Relation "Principes chimiques et Activité antimicrobienne Pharm. Méd. Trad. Afro 1995; pp 4344

15. Traore F, Gasquet M, Laget M. Toxicity and genotoxicity of antimalarial alkaloid rich extracts derived from Mitragyna inermis 0 . Kuntze and Nauclea latifolia Phytoter Res. 2000; 14: 608-611

16. Arise RO, Akintola AA, Olarinoye IB, Balogun EA. Effects of aqueous extract of Nauclea latifolia stem on lipid profile and some enzymes of rat liver and kidney. Int J Pharmacol. 2012; 8: 389-395.

17. OCDE 401 (Organisation de Coopération et de Développement Economiques). Ligne directrice pour les essais de produits chimiques: "Toxicité orale aiguë», 1987; $p 8$.

18. OCDE 407 (Organisation de Coopération et de Développement Economiques). Ligne directrice pour les essais de produits chimiques: "Toxicité orale à dose répétée - pendant 28 jours sur les rongeurs», 2008 ; pp 3-5.

19. Delongeas JC, Brunel D, Netter $P$, Grignon M, Mur JM, Roger GM. Toxicité et Pharmacocinétique de l'oxychlorure de zirconium chez la souris et le rat. J. de Pharmacol. 1983 ; 14: 437-445.

20. Enriques JB. Les médicaments anthelminthique utilisés en médecine des carnivores domestiques. Activité et toxicité, Recueil de Méd. Vét. 1983 ; 189: 499-454.

21. Taiwe GS, Bum EN, Dimo $T$, Talla Weiss $N$. Antidepressant, myorelaxant and anti-anxiety-like effects of Nauclea latifolia smith (Rubiaceae) roots extract in murine models. Int. J. Pharmacol. 2010; 6: 364-371.

22. Gamaniel KS. Sub-acute Toxicity Studies on the Aqueous Extracts of Nauclea latifolia in rats -Afr $J$ Trad Compl Altern Med 2005; 2: 177-205

23. Kaiya MS, Thansborg SM. Effect of Acacia nilotica and Acacia karoo diets on haemonchus contortus in goats. Vet Parasitol 2003; 115: 265-272.

24. Spencer CON, Sunday JJ, Teslimat EA, Kazeem OA, Eguagie OO, Akinola AA. Comparative effects of aqueous and ethanolic leaf extracts of Gongronema latgfolium on sen1rn kidney and liver biomarkers of normal male rats. Asian I Biol Sci 2011; 4: 540-547.

25. Stroev EA; Makarova VA. Quantitative Estimation of Enzymatic Activity. In: Stroev EA, Ed. Laboratory Manual in Biochemistry, 2nd edn, Moscow: Mir Publishers; 1989; pp 37-44. 